\title{
ANALISIS FAKTOR-FAKTOR YANG MEMPENGARUHI PERILAKU MENYIMPANG PADA ANAK USIA SEKOLAH DASAR DI SD NEGERI PLEBURAN 03 SEMARANG
}

\author{
Atikah Dewi Anggita1, Iin Purnamasari², Rahmat Rais ${ }^{3 凶}$ \\ ${ }^{123}$ PGSD, Universitas PGRI Semarang
}

\section{Info Artikel}

Sejarah Artikel:

Disubmit: Februari 2021

Direvisi: Februruari 2021

Diterima: Mei 2021

\section{Keywords:}

deviant behavior

\begin{abstract}
Abstrak
Penelitian ini dilatar belakangi oleh banyaknya anak usia sekolah dasar di SD Pleburan 03 Semarang yang melakukan perilaku menyimpang. Penelitian ini bertujuan untuk mengetahui bentuk perilaku menyimpang, faktor yang mempengaruhi perilaku menyimpang, dan upaya yang dilakukan untuk menangani perilaku menyimpang pada anak. Penelitian ini merupakan penelitian deskriptif kualitatif. Hasil penelitian menunjukkan bahwa bentuk perilaku menyimpang yang dilakukan adalah berbohong, menyontek, mengganggu orang lain, membuat kegaduhan, terlambat, mencoret-coret dinding/meja/kursi, membolos, mengejek, meninggalkan kelas tanpa ijin, berkelahi, tidur dikelas ketika pelajaran, tidak memperhatikan guru, tidak melaksanakan piket, memalak, melawan guru, merusak barang orang lain, mencuri, merokok, menggunakan senjata tajam. Faktor yang mempengaruhi yaitu karena ketidaksanggupan menyerap normanorma kebudayaan, proses belajar yang menyimpaang, ketegangan antara kebudayaan dan struktur sosial, ikatan sosial yang berlainan dan akibat proses sosisalisasi nilai subkebudayaan yang menyimpang. Upaya yang diberikan untuk menangani perilaku menyimpang pada anak yaitu tindakan preventif, tindakan represif, tindakan kuratif, dan tindakan persuasif.
\end{abstract}

\section{Abstract}

This research is motivated by the large number of elementary school age children at $S D$ Pleburan 03 Semarang who practice deviant behavior. This study aims to determine the form of deviant behavior, the factors that influence deviant behavior, and the efforts made to deal with deviant behavior in children. This research is a qualitative descriptive study. The results showed that the forms of deviant behavior were lying, cheating, disturbing others, making noise, being late, scribbling on walls / tables / chairs, skipping classes, teasing, leaving class without permission, fighting, sleeping in class during lessons, not paying attention. teachers, not carrying out pickets, yelling, fighting against teachers, destroying other people's things, stealing, smoking, using sharp weapons. The influencing factors are due to the inability to absorb cultural norms, the learning process that strikes, the tension between culture and social structures, different social ties and the consequence of the socialization of deviant sub-cultural values. Efforts are given to address deviant behavior in children, namely preventive action, repressive action, curative action, and persuasive action.

C 2021 Universitas Negeri Semarang

\begin{tabular}{lr}
\hline Alamat korespondensi: & ISSN 2252-7133 \\
PGSD UPGRIS & E-ISSN 2548-4648 \\
E-mail: Atikahdewia16@gmail.com &
\end{tabular}




\section{PENDAHULUAN}

Anak usia sekolah dasar berada dalam proses perkembangan yang berlangsung dengan cepat dalam aspek fisik, emosional, intelektual dan sosial. Dalam perkembangannya anak juga harus mendapat perlindungan. Perlindungan anak merupakan hal yang sangat penting untuk menjamin bahwa hak-hak anak benar-benar dinikmati secara utuh. Perlindungan anak menurut Undang-Undang Nomor 35 Tahun 2014 adalah segala kegiatan untuk menjamin dan melindungi anak dan hak-haknya agar dapat hidup, tumbuh, berkembang dan berpartisipasi secara optimal sesuai dengan harkat dan martabat kemanusiaan, serta mendapat perlindungan dari kekerasan dan diskriminasi.

Berbagai macam perilaku yang telah dilakukan anak baik secara sadar maupun tidak sadar. Jenis perilaku menurut Fitiyah (2016:10) diketahui bahwa perilaku dibedakan antara perilaku refleksif dan perilaku nonrefleksif. Perilaku refleksif adalah perilaku yang terjadi karena reaksi secara spontan terhadap stimulus yang mana pada dasarnya tidak dapat dikendalikan, hal tersebut karena tingkah laku refleksif merupakan tingkah laku yang alami, bukan tingkah laku yang dibentuk. Sedangkan perilaku nonrefleksif adalah perilaku yang dapat dikendalikan atau dibentuk oleh pusat kesadaran dan dapat berubah dari waktu ke waktu.

Setiap tahap perkembangan anak, tak jarang anak mengalami hambatan atau bahkan melakukan perilaku yang keliru yang dapat merugikan mereka, baik untuk dirinya sendiri maupun orang lain. Pada dasarnya setiap anak mengalami tahap-tahap perkembangan yang mana anak dituntut dapat bertindak atau melaksanakan hal-hal yang menjadi tugas perkembangannya dengan baik.

Perilaku menyimpang dapat terjadi dimana saja, baik di keluarga, sekolah maupun di lingkungan masyarakat. Perilaku menyimpang bisa terjadi karena adanya penyesuaian yang harus dilakukan oleh anak terhadap kondisi dan tuntutan lingkungan. Perilaku menyimpang yang terjadi pada anak sekolah dasar memiliki dampak terhadap kehidupan untuk masa yang akan datang

Penyimpangan bisa didefinisikan sebagai setiap perilaku yang tidak berhasil menyesuaikan diri dengan kehendakkehendak masyarakat atau kelompok tertentu dalam masyarakat. Menurut James W. Van der Zander (dalam Hisyam 2018: 4) mengemukakan bahwa perilaku menyimpang merupakan perilaku yang dilakukan sejumlah orang sebagai hal yang tercela dan di luar batas toleransi sebagian besar masyarakat.

Bentuk perilaku menyimpang dikalangan anak usia sekolah dasar sangat beragam mulai dari kebohongan, ejekan, pemukulan, juga kontak fisik lainnya. Anak usia sekolah dasar di SD Negeri Pleburan 03 Semarang masih banyak yang belum dapat menjaga ketertiban sekolah, mereka bertingkah laku yang merugikan orang lain dan bahkan dapat merugikan diri mereka sendiri.

Penyebab tingkah laku menyimpang tersebut diantaranya adalah kegagalan dalam proses sosialisasi sehingga keluarga memiliki peran untuk bertanggung jawab terhadap penanaman nilai dan norma pada anak. Kegagalan proses pendidikan dalam keluarga inilah yang dapat menyebabkan terjadinya penyimpangan terhadap tingkah laku anak. Penyimpangan pada anak usia sekolah dasar tidak mudah terjadi apabila guru dan orangtua bekerjasama dalam mendidik anak.

Peran pendidikan dalam membentuk kepribadian atau perilaku anak sangat diharapkan. Pendidikan memberikan seseorang modal pengetahuan dan kompetensi yang dibutuhkan untuk membuat pembendaan atau penaksiran nilai. Nilai sopan santun, malu, kerja keras, kejujuran, kepercayaan, dan lain-lain yang dibentuk, diperkuat, dan dipertahankan terutama melalui pendidikan formal yaitu sekolah. (Kusdaryani, W., Purnamasari, I dan Damayani, A.T, 2016) 
Guru diharapkan dapat memberikan nilai-nilai positif terhadap anak untuk membentuk sikap yang baik pada diri anak. Pengendalian perilaku anak tidak cukup dilakukan oleh guru saja, melainkan juga oleh orang tua.

Berdasarkan banyaknya perilaku menyimpang yang dilakukan anak usia sekolah dasar di SD N Pleburan 03 Semarang maka peneliti melakukan analisis secara mendalam melalui penelitian tentang faktorfaktor yang mempengaruhi perilaku menyimpang pada anak usia sekolahdasar di SD N Pleburan 03 Semarang.

\section{METODE PENELITIAN}

Metode penelitian yang digunakan adalah deskriptif dengan pendekatan kualitatif. Moleong (2017: 6) berpendapat bahwa penelitian kualitatif adalah penelitian yang bermaksud memahami fenomena tentang apa yang dialami oleh subjek penelitian misalnya perilaku, persepsi, motivasi, tindakan, dan lain-lain, secara holistic dengan cara deskripsi dalam bentuk kata-kata dan bahasa.

Penelitian deskriptif yaitu suatu penulisan yang menggambarkan keadaan yang sebenarnya tentang objek yang diteliti, menurut keadaan yang sebenarnya pada saat penelitian berlangsung. Pada penelitian ini peneliti mendeskripsikan masalah yang diteliti dengan keadaan sesungguhnya yang terjadi di SD N Pleburan 03 Semarang dengan observasi, wawancara, pengisian angket dan sumber lain yang berkaitan dengan masalah penelitian kemudian disajikan dalam bentuk kalimat deskriptif.

\section{HASIL DAN PEMB AHASAN B entuk Perilaku Menyimpang}

Dari hasil penelitian dan analisis data yang telah dilakukan maka diperoleh informasi bahwa bentuk perilaku menyimpang yang dilakukan anak usia sekolah dasar bermacam-macam yaitu $60 \%$ anak usia sekolah dasar di SD N Pleburan 03 Semarang berbohong yang mana berbohong merupakan perilaku menyimpang yang bisa dilakukan secara individu maupun kelompok, $42 \%$ anak pernah menyontek, $37 \%$ mengganggu orang lain, $36 \%$ mengejek orang lain, $24 \%$ mencoret-coret dinding, meja, kursi sekolah, dan 4\% lainnya merusak fasilitas sekolah atau barang milik orang lain.

Perilaku menyimpang lain yang dilakukan yaitu $21 \%$ anak usia sekolah dasar di SD N Pleburan 03 Semarang membuat kegaduhan dan kerusuhan baik di dalam kelas maupun diluar kelas, 20\% anak pernah berkelahi dengan temannya, $14 \%$ pernah dengan sengaja membolos, 9\% terlambat datang ke sekolah, $11 \%$ pernah meninggalkan kelas tapa ijin, $10 \%$ tidak memperhatikan ketika guru menjelaskan, dan $10 \%$ pernah dengan sengaja untuk tidak melaksanakan piket, didapatkan pula $6 \%$ anak pernah mengambil barang milik orang lain, 2\% pernah memalak dan melawan guru, serta penyimpangan lain yang pernah dilakukan yaitu pernah didapatkan bahwa ada anak yang membawa dan menggunakan senjata tajam ketika sedang emosi dan menodongkan ke orang lain, ada pula beberapa anak yang pernah merokok. Selain itu terdapat pula sekumpulan anak atau genk yang mana biasanya bertindak kerusuhan atau menganggu orang lain.

Berdasarkan berbagai macam perilaku menyimpang yang dilakukan anak usia sekolah dasar di SD N Pleburan 03 Semarang maka bentuk perilaku menyimpang dapat dikelompokkan menjadi penyimpangan individu, penyimpangan kelompok dan penyimpangan campuran sejalan dengan pendapat Hisyam (2018: 11) yang menyatakan bahwa penyimpangan individu yaitu penyimpangan yang dilakukan oleh individu ataau perorangan dengan tujuan karena tidak dapat menyesuaikan dengan norma sehingga dengan sengaja melakukan penyimpangan dengan melanggar norma yang berlaku. Penyimpangan kelompok yaitu penyimpangan yang dilakukan oleh sekelompok orang yang tidak mematuhi nilai dan norma yang berlaku. Penyimpangan campuran yaitu penyimpangan dilakukan oleh individu dalam sebuah kelompok yang nantinya dapat mempengaruhi orang lain sehingga ikut melakukan tindakan menyimpang. 
Faktor yang Mempengaruhi Perilaku Menyimpang

Perilaku menyimpang yang dilakukan oleh anak usia sekolah dasar yaitu berbagai macam, dari hasil penelitian dan analisis didapatkan bahwa perilaku menyimpang dapat terjadi karena dari dirinya sendiri kurangnya penguatan diri sehingga ada dorongan dari dirinya sendiri untuk melakukan perilaku menyimpang, penyebab lain yang mempengaruhi perilaku menyimpang pada anak yaitu dari keluarga yang mana keluarga memiliki peran penting dalam terbentuknya perilaku untuk anak, sejalan dengan Wahab (2015: 2) yang menyatakan bahwa posisi keluarga mempunyai peran yang sangat besar dalam mempengaruhi kehidupan dan perilaku pada anak. Kedudukan dan fungsi keluarga bersifat fundamenatal karena keluarga merupakan wadah pemebentukan watak dan akhlak bagi anak.

Apabila orang tua kurang memberikan perhatian maka anak akan mencari perhatian dari orang lain dengan cara melakukan perilaku menyimpang, orang tua yang memberikan salah asuhan atau didikan pun akan mempengaruhi anak untuk melakukan perilaku menyimpang karena anak salah menerima didikan yang diberikan oleh orang tuanya.

Selain itu perilaku menyimpang juga dipengaruhi karena pergaulan anak yang mana teman pergaulan dapat mempengaruhi anak dengan sebuah ajakan untuk melakukan perilaku menyimpang. Tayangan dari media massa juga mempengaruhi anak melakukan perilaku menyimpang dengan pernah melihat maupun mendengar maka anak akan terpengaruh untuk melakukan perilaku menyimpang.

Berdasarkan berbagai macam faktor yang telah disampaikan maka secara garis besar faktor yang mepengaruhi perilaku menyimpang yaitu karena ketidaksanggupan menyerap norma-norma kebudayaan, proses belajar yang menyimpaang, ketegangan antara kebudayaan dan struktur sosial, ikatan sosial yang berlainan dan akibat proses sosisalisasi nilai-nilai subkebudayaan yang menyimpang.

Hal itu sejalan dengan teori yang dikemukakan oleh Hisyam (2018: 9) yaitu beberapa penyebab terjadinya penyimpangan yaitu: 1) ketidaksanggupan menyerap norma-norma kebudayaan, seseorang yang tidak sanggup menyerap norma kebudayaan kedalam dirinya maka tidak dapat membedakan hal pantas dan tidak pantas, terjadi akibat keluarga yang tidak bisa mendidik anaknya anaknya sempurna, 2) Proses belajar yang menyimpang, disebabkan karena seringnya membacaa atau melihat tayangan tentang perilaku menyimpang kemudian meniru, 3) Ketegangan antara Kebudayaan dan Struktur Sosial, hal ini terjadi dalam upaya mencapai suatu tujuan pelaku tidak memperoleh peluang sehingga mengupayakan peluang sendiri, 4) Ikatan sosial yang berlainan, terjadi apabila dalam pergaulan mempunyai pola perilaku yang menyimpang maka kemungkinan ia juga akan mencontoh, 5) Akibat proses sosialisasi nilai subkebudayaan yang menyimpang, banyaknya media massa menampilkan berita atau tayangan terkait perilaku menyimpang mengakibatkan proses belajar menyimpang akan dilakukan.

\section{Upaya yang Dilakukan Untuk Menangani Perilaku Menyimpang}

Upaya yang dilakukan untuk menangani perilaku menyimpang pada anak usia sekolah dasar di SD N Pleburan 03 Semarang yaitu dengan adanya peran keluarga dan lingkungan sekitar untuk menumbuhkan nilai moral karakter baik terhadap anak. Peran orang tua membesarkan anak dan mengasuh anak bukanlah hal yang mudah, dibutuhkan kekompakkan dan kompromi masing-masing orang tua dalam mempraktikkan konsep dan tujuan pola asuh yang sesuai dengan karakter anak. Beragam perkembangan mulai dari fisik, kognisi, emosi dan sosial sangat dipengaruhi oleh orangtua dalam menerapkan pola asuh dalam keseharian.

Tidak hanya keluarga dan orang tua peran pendidikan diharapkan mampu menanamkan pendidikan karakter yang baik 
pada saat di sekolah, selain itu dengan memberikan pengendalian preventif yaitu dengan pengambilan tindakan pencegahan terhadap kemungkinan terjadinya suatu pelanggaran, seperti dengan memberikan nasihat. Pengendalian represif yaitu dengan memberikan sanksi hukuman. Pengendalian kuratif, yaitu dengan menggabungkan antara tindakan nasihat dan sanksi hukuman agar pelaku menjadi jera dan pengendalian persuasif dengan cara tanpa kekerasan yaitu dengan memberi peringatan melalui media dan tanpa menjatuhkan hukuman fisik.

Perilaku menyimpang yang ditemukan di SD N Pleburan 03 Semarang, sangat dimungkinkan merupakan perilaku menyimpang pada anak usia sekolah dasar pada umumnya.

\section{KESIMPULAN}

Berdasarkan hasil penelitian dan pembahasan dapat disimpulan bahwa bentuk perilaku menyimpang yang sering dilakukan anak usia sekolah dasar di SD N Pleburan 03 Semarang yaitu berbohong, mengejek, menyontek, menganggu orang lain, berkelahi, membuat kegaduhan, merusak fasilitas sekolah, mencoret dinding/meja/kursi, datang terlambat ke sekolah, membolos, meninggalkan kelas tanpa ijin, tidur saat jam pelajaran, tidak memperhatikan ketika guru menjelaskan.

Faktor yang mempengaruhi anak untuk melakukan perilaku menyimpang yaitu karena ketidaksanggupan menyerap normanorma kebudayaan, proses belajar yang menyimpang, proses belajar yang menyimpang, ketegangan antara kebudayaan dan struktur sosial, ikatan sosial yang berlainan dan akibat proses sosialisasi nilainilai subkebudyaan yang menyimpang.

Sehingga upaya yang diberikan untuk menangani perilaku menyimpang pada anak usia sekolah dasar di SD N Pleburan 03 Semarang yaitu dengan memberikan pengendalian preventif yaitu dengan pengambilan tindakan pencegahan terhadap kemungkinan terjadinya suatu pelanggaran, seperti dengan memberikan nasihat. pengendalian represif yaitu dengan memberikan sanksi hukuman. Pengendalian kuratif, yaitu dengan menggabungkan antara tindakan nasihat dan sanksi hukuman agar pelaku menjadi jera dan pengendalian persuasif dengan cara tanpa kekerasan yaitu dengan memberi peringatan melalui media dan tanpa menjatuhkan hukuman fisik.

\section{DAFTAR PUSTAKA}

Bimo, W. (2010). Pengantar Psikolog Umum. Yogyakarta: C.V Andi.

Burlian, Paisol. (2016). Patologi Sosial. Jakarta. PT. Bumi Aksara.

Fitriyah, L. (2016). Pengantar Psikologi Umum. Jakarta: Prestasi Pusatkarya.

Hisyam, C. J. (2018). Perilaku Menyimpang: Tinjauan Sosiologi. Jakarta: Bumi Aksara.

Kusdaryani, W., Purnamasari, I. \& Damayani, A.T. (2016). Penguatan Kultur Sekolah untuk Mewujudkan Pendidikan Ramah Anak. Cakrawala Pendidikan. Th.XXXV (1), 125-133.

Moleong, L. J. (2016). Metode Penelitian KualitatifEdisi Revisi. Bandung: PT. Remaja Rosdakarya.

Undang-Undang Nomor 35 Tahun 2014 Tentang Perubahan Atas UndangUndang Nomor 23 Tahun 2002 Tentang Perlindungan Anak.

Wahab, Abdul. (2015). Konsep Orang Tua Dalam Membangun Kepribadian Anak. Jumal Paradigma. Vol ume 2 Nomor 1, Hlm.2. 